\title{
Does the laparoscopic adrenalectomy seem to be less complicated for pheochromocytoma as a pathologic adrenal mass in children? A systematic review study
}

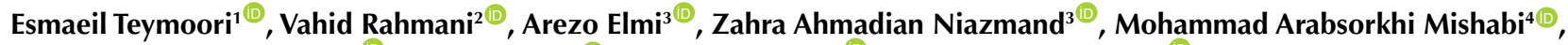 \\ Reza Mohebbi Hozesorkhi ${ }^{\circledR}$, Hamid Noori ${ }^{4}{ }^{\circledR}$, Dorrin Nikbakht ${ }^{1}$, Masoud Chahartangi ${ }^{*}{ }^{*}$ \\ 'Department of Operating Room Technology, School of Allied Medical Sciences, Iran University of Medical Sciences, Tehran, Iran \\ 2Department of Operating Room Technology, Maragheh University of Medical Sciences, Maragheh, Iran \\ 3Shohada Educational Hospital, Tabriz University of Medical Sciences, Tabriz, Iran \\ ${ }^{4}$ Student Research Committee, Iran University of Medical Sciences, Tehran, Iran \\ ${ }^{5}$ Department of Operating Room Technology, Torbat Heydariyeh University of Medical Sciences, Torbat Heydariyeh, Iran
}

*Correspondence to

Masoud Chahartangi,

Email:

masoud.iums@gmail.com

Received 1 January 2020 Accepted 18 Mar. 2020 Published online 6 May 2020

Keywords: Laparoscopic adrenalectomy,

Pheochromocytoma

Pathologic adrenal Mass,

Children, Steroid

Abstract
Introduction: This study was aimed to review the complications of the laparoscopic adrenalectomy for
pheochromocytoma.
Materials and Methods: International databases including PubMed, Web of Science and Scopus were
considered for search of English articles by 24 May 2019 . Seventeen published articles were finally entered
into the study. Keywords were adrenalectomy, laparoscopy, chromaffin, PC12 cells, pheochromocytoma and
children or a combination of them in the title and abstracts.
Results: There were more than 647 individuals reviewed in this systematic review of 17 published articles
consisted of 16 retrospective studies and one prospective study.
Conclusion: According to the results, laparoscopic adrenalectomy can be used safely with a short hospital stay
and less hemorrhagia, short time of surgery and low-risk of recurrence for the management of pediatric adrenal
pathology. It is suggested to undergo partial adrenalectomy, which provides steroid independent at long-term
follow up.

\section{Introduction}

Citation: Teymoori E, Rahmani V, Elmi A, Ahmadian Niazmand Z, Arabsorkhi Mishabi M, Mohebbi Hozesorkhi R, et al. Does the laparoscopic adrenalectomy seem to be less complicated for pheochromocytoma as a pathologic adrenal mass in children? A systematic review study. Immunopathol Persa. 2020;6(2):e20. DOI:10.34172/ ipp. 2020.20
Pheochromocytoma is a tumor of the chromaffin cells and due to the secretion of catecholamine causes significant impairment in the hemodynamic status. Less than $1 \%$ of the cause of hypertension is related to pheochromocytoma (1). Diagnosis and subsequently treatment of pheochromocytoma is necessary, since delay in the diagnosis and treatment can lead to severe and fatal complications of the tumor, such as myocardial infarction, cerebrovascular attack, mesenteric ischemia, and hemorrhagia. The prevalence of pheochromocytoma is equal in both genders since its highest prevalence is in the third to fifth decades of life (2). This tumor is known as " tumor 10 ", while $10 \%$ of cases are bilateral, $10 \%$ of cases are familiar, $10 \%$ of cases are out of the adrenal gland, $10 \%$ of cases happen in children and $10 \%$ of cases are malignant and also in $10 \%$ of cases, patients have normal blood pressure (3).

The main symptom of pheochromocytoma

\begin{abstract}
Key point
In this review paper, we showed laparoscopic adrenalectomy is safe accompanied by a short hospital stay and less hemorrhagia, short time of surgery and low-risk of recurrence for the management of pediatric adrenal tumors.
\end{abstract}

is hypertension (4). More than $80 \%$ of patients have urinary catecholamine more than twice the normal while catecholamine in the plasma is also greater than $2000 \mathrm{~L} /$ ng. In case of diagnosis, the core treatment is a surgery requiring special modalities to neutralize tumor catecholamine due to manipulation during the invasive procedure and anesthetic induction, which achievable using beta-blocker for 2 to 3 weeks (2). Pheochromocytoma is characterized by a medical history and measuring urinary or plasma catecholamine or their metabolites or radiological studies. A high urinary catecholamine level in $95 \%$ of cases is causes

\footnotetext{
Copyright (c) 2020 The Author(s); Published by Nickan Research Institute. This is an open-access article distributed under the terms of the Creative Commons Attribution License (http://creativecommons.org/licenses/by/4.0), which permits unrestricted use, distribution, and reproduction in any medium, provided the original work is properly cited.
} 
symptoms and is a suitable test (5).

Most cases of pheochromocytoma are non-familial, but in some familial cases, it is often bilateral. The inherited autosomal type is multiple endocrine neoplasia type 2 syndrome (MEN2) that ranges from $0.1 \%$ to $5.7 \%$ (6). The MEN2 is bilateral requiring bilateral adrenalectomy while its mortality is $2.4 \%$ and morbidity is about $24 \%$ (7). Treatment of malignant pheochromocytoma is also a surgical procedure since metastasis should be removed; pheochromocytoma can be followed by chemotherapy. A 5 -year survival after surgery is about $95 \%$ and recurrence is less than $10 \%(8)$. Nowadays, surgical treatment for adrenal removal is laparoscopy (9). At first, laparoscopic adrenalectomy was reported in 1992 (10).

To the best of our knowledge, there is no systematic review regarding the laparoscopic adrenalectomy in children. There are some systematic reviews about the comparison between laparoscopic adrenalectomy and other procedures e.g. in the review study by Brandao et al (11), on robotic versus laparoscopic adrenalectomy" or in the review study by Chai et al (12), entitled "systematic review of surgical approaches for adrenal tumors; lateral transperitoneal versus posterior retroperitoneal and laparoscopic versus robotic adrenalectomy", the comparison of the methods were compared and the results were consistent by the study of Whalen et al (13), however we comprehensively reviewed the efficacy of laparoscopic adrenalectomy in children.

\section{Methods}

\section{Search strategy}

In this systematic review, international databases including PubMed, Web of Science and Scopus were considered for search of English articles from 1 January 1992 to 31 April 2019. We included patients less than 18 years who experienced laparoscopicadrenalectomy (Notlaparotomy). All type of articles was included while case series less than five cases report. Keywords were ((( adrenalectomy [Title/Abstract]) OR laparoscopy [Title/Abstract]) OR laparoscopic adrenalectomy [Title/Abstract]) AND (((chromaffin [Title/Abstract]) OR PC12 cells [Title/ Abstract]) OR pheochromocytoma [Title/Abstract]) OR pheochromocytoma [Title/Abstract])) AND ((Children [Title/Abstract]) OR (Child [Title/Abstract])) AND ((“1992/01/01”[PDat]: “2019/04/31”[PDat])).

After collection of articles of interest, references imported to Endnote software and removed duplicate titles. Then, after browsing titles, studies with irrelevant purposes were removed, and then the remaining studies assessed by two independent investigators. The selected studies were performed on humans and published in English. All steps of systematic review were performed in this review (Figure 1).

\section{Data extraction}

Information dealing with the selected articles (the author's

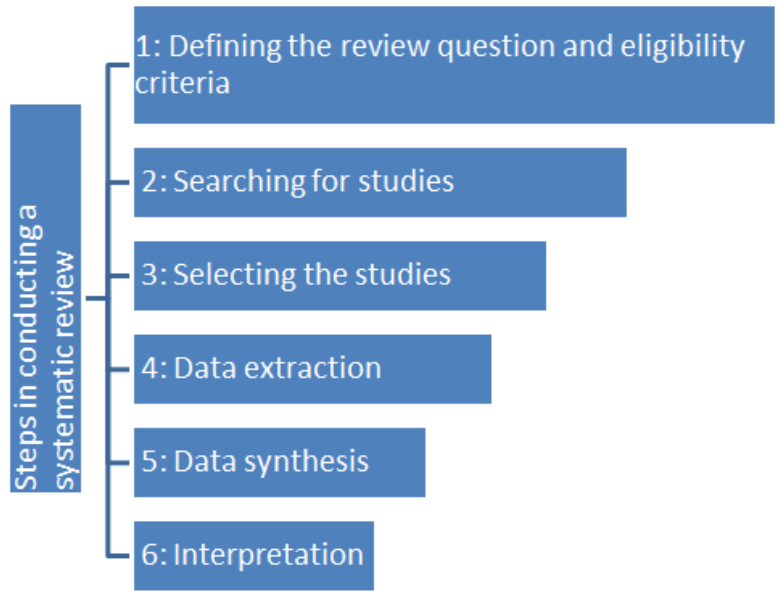

Figure 1. Steps in conducting a systematic review.

last name, year of publication, study design, sample size and the results of each article were taken by two independent investigators. The differences observed in this process corrected by a third investigator who was independent with the two previous investigators.

\section{Results}

There were more than 647 individuals reviewed in this systematic review of 17 published articles consisted of sixteen retrospective studies and one prospective study.

We used the Preferred Reporting Items for Systematic Reviews and Meta-Analyses (PRISMA) checklist, a checklist of items that should be included in reports of interventional studies for selected articles (Figure 2) (14). The summary of the selected articles was shown in Table 1.

\section{Discussion}

The mean age of patients with pheochromocytoma is reported 11 years; hence in boys occur twice than girls (31).

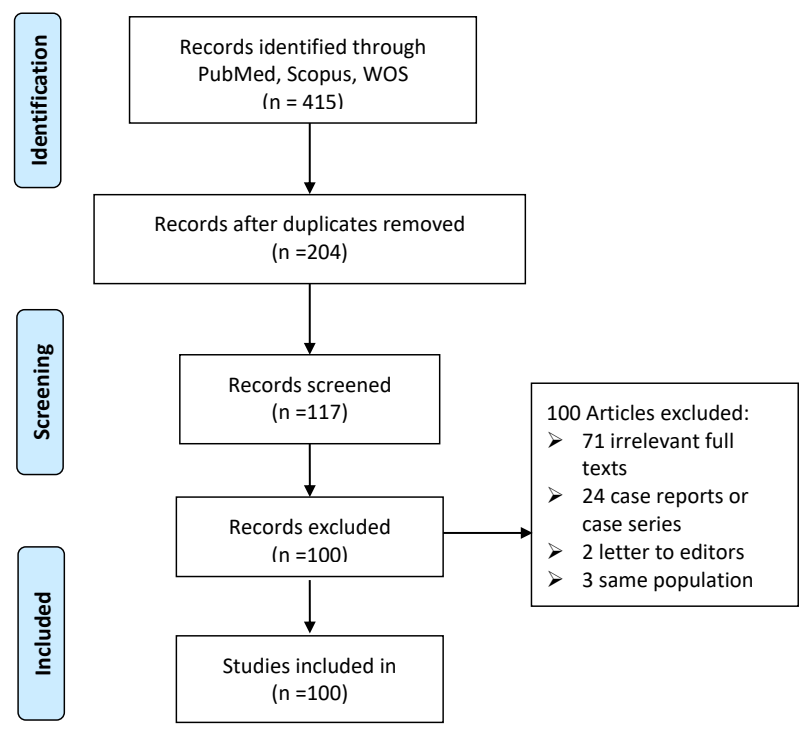

Figure 2. Flow chart of study selection based on PRISMA. 
Table 1. The detail of reviewed articles in this systematic study

\begin{tabular}{|c|c|c|c|c|c|c|c|c|}
\hline ID & First author & $\mathbf{N}$ & Age & Sex & Side & Tumor Size & Design & Conclusion \\
\hline 1 & Castilho et al, 2002 (15) & 13 & 6.3 & Both & Unilateral & $4.14 \mathrm{~cm}$ & Retrospective & Laparoscopic adrenalectomy is feasible accompanied by positive results in children. \\
\hline 2 & Sukumar et al, 2011 (16) & 10 & 9.6 & Both & $\begin{array}{l}\text { 7: Unilateral } \\
\text { 3: Bilateral }\end{array}$ & $4.8 \mathrm{~cm}$ & Retrospective & It is possible to perform adrenalectomy in children with experienced surgeons. \\
\hline 3 & Volkin et al, 2012 (17) & 10 & 7.2 & Both & $\begin{array}{l}\text { 8: Unilateral } \\
\text { 2: Bilateral }\end{array}$ & $2.6 \mathrm{~cm}$ & Retrospective & $\begin{array}{l}\text { Partial adrenalectomy is the preferred form of management for pheochromocytom in the pediatric population to preserve } \\
\text { adrenocortical function and minimize the adverse effects in front of long-term steroid. }\end{array}$ \\
\hline 4 & Nerli et al, 2010 (18) & 18 & 5.8 & Both & Unilateral & $4 \mathrm{~cm}$ & Retrospective & $\begin{array}{l}\text { Laparoscopic adrenalectomy is a safe and feasible procedure with good results. It can be used to safely treat suspected benign and } \\
\text { malignant adrenal masses in children with minimal morbidity and a shorter hospital stay. }\end{array}$ \\
\hline 5 & Lopes et al, 2011 (19) & 17 & 3.9 & Both & $\begin{array}{l}\text { 15: Unilateral } \\
\text { 2: Bilateral }\end{array}$ & $4.27 \mathrm{~cm}$ & Retrospective & $\begin{array}{l}\text { Laparoscopic adrenalectomy is a feasible procedure that produces good results. It can be used safely to treat suspected benign and } \\
\text { malignant adrenal masses in children with minimal morbidity and short hospital stay. }\end{array}$ \\
\hline 6 & Emre et al, 2019 (20) & 50 & 4.8 & Both & $\begin{array}{l}\text { 46: Unilateral } \\
\text { 4: Bilateral }\end{array}$ & $13.88 \mathrm{~cm}$ & Retrospective & $\begin{array}{l}\text { The histopathology of the mass is crucial determinant for determining the surgical approach to in pediatric, as well as volume. } \\
\text { Minimally invasive procedures could be reliably performed in appropriate cases. }\end{array}$ \\
\hline 7 & Lee et al, 2019 (21) & 20 & 4 & Both & Unilateral & $7.12 \mathrm{~cm}$ & Retrospective & Posterior retroperitoneoscopic adrenalectomy is resulted in good outcome in children (with prone jackknife position). \\
\hline 8 & de Barros et al, 2012 (22) & 7 & 2.25 & Both & Unilateral & $2.8 \mathrm{~cm}$ & Retrospective & $\begin{array}{l}\text { The laparoscopic approach for adrenal neuroblastoma resection is feasible in children with good outcomes, but should be reserved } \\
\text { to patients with small, well-circumscribed adrenal lesions, without invasive or infiltrative disease. }\end{array}$ \\
\hline 9 & Catellani et al, 2014 (23) & 9 & 7.25 & Both & Unilateral & $3.23 \mathrm{~cm}$ & Retrospective & $\begin{array}{l}\text { Laparoscopic adrenalectomy is a safe, feasible, and reproducible technique offering numerous advantages, including shortening } \\
\text { the times of surgery and postoperative hospital stays and less hemorrhagia. Laparoscopic adrenalectomy provides visible surgery } \\
\text { site. }\end{array}$ \\
\hline 10 & $\begin{array}{l}\text { Fascetti-Leon et al, } 2017 \\
(24)\end{array}$ & 68 & 5.2 & Both & $\begin{array}{l}\text { 65: Unilateral } \\
\text { 3: Bilateral }\end{array}$ & $2.8 \mathrm{~cm}$ & Retrospective & $\begin{array}{l}\text { Pediatric Minimal access adrenal surgery (MAAS) is safe adopted for masses up to } 145.6 \mathrm{cc} \text {, with less low complication. Conversion } \\
\text { to open is not necessary even in the presence of infiltrations. }\end{array}$ \\
\hline 11 & Cho et al, 2012 (25) & 8 & 12 & Both & Unilateral & $18.3 \mathrm{~cm}$ & Retrospective & Complete tumor resection was successful, with no tumor recurrence. \\
\hline 12 & Ludwig et al, 2007 (26) & 15 & 11.9 & Both & Unilateral & $3.2 \mathrm{~cm}$ & Retrospective & Laparoscopic adrenalectomy can be used safely as a preferred approach for pediatric at risk for vulnerability. \\
\hline 13 & Miller et al, 2002 (27) & 17 & 9.8 & Both & Unilateral & $4.8 \mathrm{~cm}$ & Retrospective & $\begin{array}{l}\text { Laparoscopic adrenalectomy can be used safely with a short hospital stay and less hemorrhagia in children for the management } \\
\text { of pediatric adrenal pathology. }\end{array}$ \\
\hline 14 & Peter et al, $2011(28)$ & 140 & 8.9 & Both & $\begin{array}{l}\text { 135: Unilateral } \\
\text { 5: Bilateral }\end{array}$ & $3.8 \mathrm{~cm}$ & Retrospective & $\begin{array}{l}\text { The laparoscopic approach can be used with a } 90 \% \text { chance of finishing the surgery without conversion. The risk of hemorrhagia or } \\
\text { other complications is low as a preferred approach for children. }\end{array}$ \\
\hline 15 & Stanford et al, 2002 (29) & 64 & 14 & Both & Unilateral & $5.5 \mathrm{~cm}$ & Retrospective & It can be expected to lower the hospital stay without increasing surgery time or complications. \\
\hline 16 & Walz et al, 2017 (30) & 42 & 15.6 & Both & $\begin{array}{l}\text { 38: Unilateral } \\
\text { 4: Bilateral }\end{array}$ & $2.7 \mathrm{~cm}$ & Prospective & $\begin{array}{l}\text { Pheochromocytomas should preferably be removed by minimally invasive surgery in children. Partial adrenalectomy provides } \\
\text { long-term steroid independence accompanied by low recurrence rate. }\end{array}$ \\
\hline
\end{tabular}


The most manifestation of this disease is hypertension (32). There is a strong correlation between the tumor size and the severity of symptoms as well as the secretion of catecholamine; its recurrence can be up to $12 \%$ (33).

In summary, the interpretation of the reviewed studies in the present systematic review indicated that laparoscopic adrenalectomy is possible to perform adrenalectomy in children with experienced surgeons; partial adrenalectomy is the preferred form of management for pheochromocytoma in the pediatric population to preserve adrenocortical function and minimize the adverse effects in front of long-term steroid. It has minimal morbidity and a shorter hospital stay. Posterior retroperitoneoscopic adrenalectomy resulted in a good outcome in children with prone jackknife position. Additionally, laparoscopic adrenalectomy in children is effective and safe. Clipless laparoscopic approach conducted by a skilled surgeon is recommended because it is feasible, and reproducible technique offering numerous advantages including shortening the times of surgery and postoperative hospital stays and less hemorrhagia; laparoscopic adrenalectomy provides visible surgery site (15-20).

Most of cases who developed pheochromocytoma were unilateral, therefore laparoscopic adrenalectomy can be used safely as a preferred approach for pediatrics who are vulnerable to health risks (21-29).

Walz et al showed that pheochromocytoma should preferably be removed by minimally invasive surgery in children. Partial adrenalectomy provides long-term steroid independence accompanied by low recurrence rate (29). The results of the study by Walz et al were consistent with the study of Volkin et al, therefore partial adrenalectomy was addressed as a preferred form of management for pheochromocytoma in the pediatric population to preserve adrenocortical function and minimize the adverse effects in front of long-term steroid. In this regard, the complications of steroids can be prevented indicating the major advantage of partial adrenalectomy in children (17). Although the tumor is rare, it should be considered in the following patients and should be checked: 1) headache, excessive sweating (diaphoresis) and tachycardia with or without hypertension; 2) family history of pheochromocytoma; 3) clinical pattern consistent with MEN II, or paraganglioma-pheochromocytoma syndrome; 4) Known mutation in the rearranged during transfection (RET) of cells of the patient or their family; 5) uncertain adrenal tumor; 6) unreasonable hypertension with poor response to standard treatments; and 7) hypertension and clear tachycardia in response to general anesthesia, surgery, or drug (34).

\section{Conclusion}

According to the results, laparoscopic adrenalectomy can be used safely with a short hospital stay and less hemorrhagia, short time of surgery and low risk of recurrence for the management of pediatric adrenal pathology. It is suggested to conduct partial adrenalectomy, which provides steroid independent at long-term follow up. Actually, laparoscopic adrenalectomy is feasible and showed positive results in pediatric patients.

Authors' contribution

Study concept and design: ET, VR, AE and ZAN. Search strategy: MAM, MC and RMH. Extraction of data: HN and DN. Interpretation of data: MAM and ET. Draft of the manuscript: ZAN and DN. Final revision: $\mathrm{RMH}$ and VR. Study supervision: MC and ET.

Conflicts of interest

The authors declare that there is no conflict of interest in this study.

Ethical considerations

Ethical issues (including plagiarism, misconduct, data fabrication, falsification, double publication or submission and redundancy) have been completely observed by the authors.

\section{Funding/Support}

None.

\section{References}

1. Neumann HP, Young Jr WF, Eng C. Pheochromocytoma and paraganglioma. New Engl J Med. 2019 Aug 8; 381(6):552-65.

2. Jankovic R, Diklic A, Paunovic I. Results of surgical treatment of pheochromocytoma at the institute of endocrinocopy of the clinical of Serbia in Belgrad. Srp Arh Celok Lek. 2002;130 Suppl 2:38-42.

3. Andjelkovic Z, Rravcar A. Personal experience in diagnosis and localization of pheochromocytoma. Srp Arh Celok Lek 2002; 130 suppl 2: 14-19.

4. Stein PP, Black HR. A simplified diagnostic approach to pheochromocytoma. A review of the literature and report of one institution's experience. Medicine. 1991;70(1):46-66.

5. Opocher G, Schiavi F. Genetics of pheochromocytomas and paragangliomas. Best Pract Res Clin Endocrinol Metab. 2010;24:943-956. doi:10.1016/j.beem.2010.05.001

6. Higashihara E, Nutahara K, Kato M. Laparoscopic adrenalectomy: Alternative or new standard? Curr Urol Rep. 2002;3:172-8.

7. Scholz T, Eisenhofer G, Pacak K, Dralle H, Lehnert H. Current treatment of malignant pheochromocytoma. J Clin Endocrinol Metab. 2007;92:1217-25. doi: 10.1210/jc.2006-1544.

8. Park J, Song C, Park M, Yoo S, Park SJ, Hong S, Hong B, Kim CS, Ahn H. Predictive characteristics of malignant pheochromocytoma. Korean J Urol. 2011;52:241-6. doi: 10.4111/kju.2011.52.4.241

9. Alemanno G, Bergamini C, Prosperi P, Valeri A. Adrenalectomy: indications and options for treatment. Updates Surg. 2017;69:119-125. doi: 10.1007/s13304-017-0441-0

10. Gagner M, Lacroix A, Bolte E. Laparoscopic adrenalectomy in Cushings syndrome and pheochromocytoma. $N$ Engl Med. 1992;327:1033. doi: 10.1056/NEJM199210013271417.

11. Brandao LF, Autorino R, Laydner H, Haber GP, Ouzaid I, De Sio $\mathrm{M}$, et al. Robotic versus laparoscopic adrenalectomy: a systematic review and meta-analysis. Euro Urol. 2014;65:115461. doi: 10.1016/j.eururo.2013.09.021.

12. Chai YJ, Kwon H, Yu HW, Kim SJ, Choi JY, Lee KE, et al. Systematic review of surgical approaches for adrenal tumors: lateral transperitoneal versus posterior retroperitoneal and laparoscopic versus robotic adrenalectomy. Int J Endocrinol. 2014;2014:918346. doi: 10.1155/2014/918346.

13. Whalen RK, Althausen AF, Daniels GH. Extra-adrenal 
pheochromocytoma. J Urol. 1992;147:1-0.

14. Liberati A, Altman DG, Tetzlaff J,Murow C, Gotsche PC, loannidis JP et al. The PRISMA statement for reporting systematic reviews and meta-analyses of studies that evaluate healthcare interventions: explanation and elaboration. BMJ. 2009;339:b2700. doi: 10.1136/bmj.b2700

15. Castilho LN, Castillo OA, Dénes FT, Mitre Al, Arap S. Laparoscopic adrenal surgery in children. J Urol. 2002;168:221-4

16. Sukumar S, Jadhav S, Nair B, Bhat SH, Kumar GP, Mathew G. Laparoscopic adrenal surgery in children: Lessons from a single centre experience. J Minim Access Surg. 2011;7:141-4. doi: 10.4103/0972-9941.78346.

17. Volkin D, Yerram N, Ahmed F, Lankford D, Baccala A, Gupta GN, et al. Partial adrenalectomy minimizes the need for long-term hormone replacement in pediatric patients with pheochromocytoma and von Hippel-Lindau syndrome. J Pediatr Surg. 2012;47:2077-82. doi: 10.1016/j.jpedsurg.2012.07.003.

18. Nerli RB, Reddy MN, Guntaka A, Patil S, Hiremath M. Laparoscopic adrenalectomy for adrenal masses in children. J Pediatr Urol. 2011;7:182-6. doi: 10.1016/j. jpurol.2010.04.006.

19. Lopes RI, Dénes FT, Bissoli J, Mendonca BB, Srougi M. Laparoscopic adrenalectomy in children. J Pediatr Urol. 2012;8:379-85. doi: 10.1016/j.jpurol.2011.07.012.

20. Emre Ş, Özcan R, Bakır AC, Kuruğoğlu S, Çomunoğlu N, Şen HS, et al. Adrenal masses in children: Imaging, surgical treatment and outcome. Asian J Surg. 2020;43:207-12. doi: 10.1016/j.asjsur.2019.03.012.

21. Lee YT, Samsudin H, Ong CCP, Tang PH, Lim KBL, Loh AHP. Posterior retroperitoneoscopic adrenalectomy for pediatric adrenal tumors. J Pediatr Surg. 2019;54:2348-2352. doi: 10.1016/j.jpedsurg.2019.01.068.

22. de Barros F, Romão RL, de Pinho-Apezzato ML, Velhote MC, Ricardi LR, Leal AJ, et al. Laparoscopic adrenalectomy in children for neuroblastoma: report of case series. Surg Laparosc Endosc Percutan Tech. 2012;22:79-81. doi: 10.1097/ SLE.0b013e318242e549.

23. Catellani B, Acciuffi S, Biondini D, Ceccarelli PL, Cacciari A, Gelmini R. Transperitoneal laparoscopic adrenalectomy in children. JSIS. 2014;18(3). doi: 10.4293/JSLS.2014.00388.

24. Fascetti-Leon F, Scotton G, Pio L, Beltrà R, Caione P, Esposito
C, et al. Minimally invasive resection of adrenal masses in infants and children: results of a European multi-center survey. Surg Endosc. 2017;31:4505-4512. doi: 10.1007/s00464-0175506-0.

25. Cho MJ, Kim DY, Kim SC, Kim TH, Kim IK. Adrenocortical tumors in children 18 years old and younger. J Korean Surg Soc. 2012;82:246-50. doi: 10.4174/jkss.2012.82.4.246.

26. Ludwig AD, Feig DI, Brandt ML, Hicks MJ, Fitch ME, Cass DL. Recent advances in the diagnosis and treatment of pheochromocytoma in children. Am J Surg. 2007;194:792-6.

27. Miller KA, Albanese C, Harrison M, Farmer D, Ostlie DJ, Gittes G, Holcomb GW 3rd. Experience with laparoscopic adrenalectomy in pediatric patients. J Pediatr Surg. 2002; 37:979-82

28. Peter SD, Valusek PA, Hill S, Wulkan ML, Shah SS, Ferro MM, et al. Laparoscopic adrenalectomy in children: a multicenter experience. J Laparoendosc Adv Surg Tech A. 2011;21:647-9. doi: 10.1089/lap.2011.0141.

29. Stanford A, Upperman JS, Nguyen N, Barksdale E Jr, Wiener ES. Surgical management of open versus laparoscopic adrenalectomy: outcome analysis. J Pediatr Surg. 2002;37:1027-9.

30. Walz MK, lova LD, Deimel J, Neumann HPH, Bausch B, Zschiedrich S, et al. Minimally Invasive Surgery (MIS) in children and adolescents with pheochromocytomas and retroperitoneal paragangliomas: experiences in 42 patients. World J Surg. 2018;42:1024-30. doi: 10.1007/s00268-0184488-y.

31. Havekes B, Romijn JA, Eisenhofer G, Adams K, Pacak K. Update on pediatric pheochromocytoma. Pediatr Nephrol. 2009;24:943-50. doi: 10.1007/s00467-008-0888-9.

32. Guerrero MA, Schreinemakers JM, Vriens MR, Suh I, Hwang J, Shen WT, et al. Clinical spectrum of pheochromocytoma. J Am Coll Surg. 2009;209:727-32. doi: 10.1016/j. jamcollsurg.2009.09.022.

33. Beltsevich DG, Kuznetsov NS, Kazaryan AM, Lysenko MA. Pheochromocytoma surgery: epidemiologic peculiarities in children. World J surg. 2004;28:592-6.

34. Chernausek SD. Pheochromocytoma and the multiple endocrine neoplasia syndromes. In: Sperling MA (ed). Pediatric Endocrinology. Philadelphia, WB Saunders; 1996. 